\title{
Peranan Ilmu Forensik Dalam Pengungkapan Tindak Pidana Kekerasan Fisik Dalam Lingkup Rumah Tangga Yang Dilakukan Istri Terhadap Suami (Studi Kasus Putusan No.1550/Pid.Sus/2015/Pn.Mks)
}

\author{
Octo Iskandar \\ Fakultas Hukum, Universitas Bhayangkara Jakarta Raya \\ Email: octoiskandar19@gmail.com
}

Article info

Received: Feb 13, $2021 \quad$ Revised: Mar 31, $2021 \quad$ Accepted: Apr 12, $2021 \quad$ Published: Jun 10, 2021

DOI: https://doi.org/10.31599/krtha.v15i1.509

Keywords : Criminal Law, Forensic Sience, Crimes of Violence

Abstract : This research aims to determine the role of forensic science in uncovering criminal acts of physical violence in the household done by wives against husbands and to identify constraints in the implementation of the appropriate forensic science decision No. 1550/Pid.Sus/2015/Pn.Mks. From the results, this research shows that forensic science has the fundamental role in the case of No. 1550/Pid.Sus/2015/Pn.Mks as the imposition of a witness of criminal law regulated in Law Number 23 of 2004 on the Elimination of Domestic Violence by referring to the result of visum et repertum. The constraints were inevitably faced as administration report from the result of visum et repertum and the witness testimony which was convoluted and the absence of witness in the court.

Kata kunci : Hukum Pidana, Ilmu Forensik, Tindak Pidana Kekerasan

Abstrak : Penelitian ini bertujuan untuk mengetahui peran ilmu forensik dalam mengungkap tindak pidana kekerasan fisik dalam lingkup rumah tangga yang dilakukan istri terhadap suami dan untuk mengetahui kendala-kendala dalam penerapan ilmu forensik tersebut sesuai putusan No.1550/Pid.Sus/2015/Pn.Mks. Dari hasil penelitian ini menunjukkan bahwa ilmu forensik mempunyai peran yang sangat penting dalam perkara No.1550/Pid.Sus/2015/Pn.Mks sebagaimana penjatuhan saksi pidana perundang-undangan yang diatur dalam Undang-undang Nomor 23 Tahun 2004 tentang Penghapusan Kekerasan Dalam Rumah Tangga dengan mengacu pada hasil visum et repertum. Tidak terlepas pula kendala-kendala yang dihadapi berupa laporan administrasi dari hasil visum et repertum dan keterangan saksi yang berbelit-beli dan tidak hadirnya saksi dalam persidangan. 
KRTHA BHAYANGKARA | Volume 15 Number 1, June 2021

\section{PENDAHULUAN}

Dewasa ini, berbagai macam permasalahan hukum semakin marak terjadi seiring dengan perkembangan zaman, ilmu pengetahuan dan teknologi yang semakin pesat. Hal ini mengakibatkan pola tingkah laku masyarakat ikut berubah menjadi semakin kompleks. Semakin banyak pola tingkah laku manusia yang tidak sesuai dengan norma-norma yang berlaku di masyarakat.

Perilaku-perilaku yang menyimpang inilah yang dapat berujung pada suatu pelanggaran bahkan kejahatan. Kejahatan akan menimbulkan keresahan dalam kehidupan masyarakat pada umumnya. Oleh karena itu, selalu diusahakan berbagai upaya untuk menanggulangi kejahatan tersebut, meskipun dalam kenyataannya sangat sulit untuk memberantas kejahatan secara tuntas karena pada dasarnya kejahatan akan senantiasa berkembang pula seiring dengan perkembangan masyarakat. Perkembangan hukumakan selalu berkembang seiring dengan perkembangan masyarakat. Demikian pula permasalahan hukum juga akan ikut berkembang seiring dengan perkembangan permasalahan yang terjadi di masyarakat.

Salah satu dampak negatif yang timbul dari perkembangan ilmu pengetahuan dan teknologi adalah timbulnya peningkatan tipe dan modus operandi kejahatan, sehingga proses penyidikan dan penyelidikan perlu pula cara menggunakan ilmu pengetahuan dan teknologi yang moderen. Salah satu ilmu bantu untuk memecahkan masalah tersebut adalah ilmu forensik.

Setiap orang ingin mempunyai rumah tangga yang sejahtera. Dalam pencapaian rumah tangga yang sejahtera, dibutuhkan proses yang panjang. Kerja sama yang baik dalam lingkup rumah tangga akan mewujudkan suatu pencapaian yang diinginkan dalam rumah tangga tersebut. Setiap individu dalam rumah tangga dalam melaksanakan hak dan kewajibannya harus bersandar pada agama dan aturan hukum. Rumah tangga seharusnya menjadi tempat yang aman bagi para anggotanya karena keluarga dibangun oleh suamiistri atas dasar ikatan lahir dan batin di antara keduanya.

Oleh karena itu rumah tangga yang seharusnya menjadi tempat berlindung bagi anggota keluarga, justru menjadi tempat penderitaan dan penyiksaan. Menanggapi kondisi kekerasan terhadap anggota-anggota keluarga dan rumah tangga yang sudah demikian terbuka dan menimbulkan banyak korban, maka masyarakat dan pemerintah merasa perlu 
untuk menanganimasalah yang menyimpang dan menimbulkan korban antara lain bentuknya adalah kekerasan dalam rumah tangga. ${ }^{1}$

Kekerasan dalam rumah tangga yang selanjutnya disebut KDRT adalah setiap perbuatan terhadap seseorang terutama perempuan, yang berakibat timbulnya kesengsaraan atau penderitaan secara fisik, seksual, psikologis, dan/ataupenelantaran rumah tangga termasuk ancaman untuk melakukan perbuatan, pemaksaan, atau perampasan kemerdekaan secara melawan hukum dalam lingkup rumah tangga. ${ }^{2}$

KDRT merupakan salah satu jenis kekerasan yang menjadi masalah kesehatan global. Studi dari berbagai negara menunjukkan, angka kejadian KDRT berkisar antara 15- 71\%. Di Indonesia, kasus kekerasan terhadap perempuan cenderung mengalami peningkatan. Jumlah kasus kekerasan pada tahun 2010 meningkat sekitar 5 kali dibandingkan tahun 2006. KDRT merupakan kasus yang mendominasi dalam kasus kekerasan terhadap perempuan yaitu $96 \%$ pada 2010. Dalam catatan tahunan Komisi Nasional Anti Kekerasan terhadap Perempuan tahun 2011, korban KDRT yang terbanyak adalah perempuan dalam rentang usia produktif (25-40 tahun). ${ }^{3}$

Undang-undang KDRT tidak hanya ditunjuk untuk perempuan,fenomena kekerasan dalam rumah tangga dapat terjadi terhadap suami yang dilakukan oleh istri, dalam Undang- undang No. 23 Tahun 2004 tidak membedakan antara kekerasan yang dilakukan oleh istri terhadap suami, apabila seorang istri melakukan kekerasan terhadap suami dan menimbulkan akibat sebagai mana dirumuskan dalam Undangundang No. 23 Tahun 2004, maka istri akan terkena sanksi pidana sebagaimana dirumuskan dalam Undang-undang tersebut.

Berdasarkan hal-hal tersebut di atas, berikut ini rumusan permasalahan yang akan dibahas dalam penelitian ini, yaitu (1) Peranan ilmu forensik dalam mengungkap tindak pidanakekerasan fisik dalam lingkup rumah tangga yang dilakukan istri terhadap suami(studi kasus putusan no. 1550/Pid.Sus/2015/PN.Mks). (2) Kendala dalam penerapan ilmu forensik terhadap tindak pidanakekerasan fisik dalam lingkup rumah tangga yang dilakukan istri terhadap suami (studi kasus putusan no. 1550/Pid.Sus/2015/PN.Mks).

${ }^{1}$ Maria E. Pandu, 2013, Bunga Rampai Perempuan Keluarga Gender, Yayasan Bina Generasi Makassar, Makassar, hlm.93.

2 Undang-Undang Republik Indonesia No. 23 Tahun 2004 Tentang Penghapusan Kekerasan Dalam Rumah Tangga.

${ }^{3}$ Komisi Nasional Perempuan, 2011, Teror dan Kekerasan Terhadap Perempuan: Hilangnya Kendali Negara, Catatan Kekerasan Terhadap Perempuan (KTP), Komnas Perempuan, Jakarta. 
KRTHA BHAYANGKARA | Volume 15 Number 1, June 2021

\section{II.METODE PENELITIAN}

Data yang diperoleh melalui kegiatan penelitian baik primer maupun sekunder akan dianalisis secara kualitatif kemudian disajikan secara deskriptif, yaitu dengan menjelaskan, menguraikan, dan menggambarkan permasalahan beserta penyelesaiannya yang berkaitan erat dengan penulisan ini. Penggunaan teknik analisis kualitatif mencakup semua data penelitian yang telah diperoleh dari wawancara, agar membentuk deskripsi yang mendukung kualifikasi kajian ini sehingga dapat memcahkan objek permasalahan yang diteliti.

\section{III.PEMBAHASAN}

\section{A. Peranan Ilmu Forensik Dalam Mengungkap Tindak Pidana Kekerasan}

\section{Peran Dokter Dalam Penyelidikan Tindak Pidana}

Dokter adalah seorang tenaga kesehatan untuk menyelesaikan semua masalah kesehatan. Keterkaitan dokter dengan penyelidikan tindak pidana adalah seorang dokter menjadi tenaga ahli dalam melakukan pemeriksaan terhadap korban tindak pidana.

Dokter dalam melakukan tugas sehari-hari, suatu waktu dapat diminta bantuannya oleh penegak hukum, maka sangatlah baik bila dokter mengetahui tentang tata laksana penyidikan perkara pidana, mulai dari saat penyidik sampai hakim menjatuhkan keputusan. Mendatangkan seorang dokter yang diperlukan sehubungan dengan perkara tidak termasuk wewenangnya. Dokter boleh dikatakan tidak ada hubungannya kerja dengan penyelidik. Ilmu kedokteran kehakiman adalah cabang spesialistik ilmu kedokteran yang memanfaatkan ilmu kedokteran untuk kepentingan penegakan hukum, terutama pada bidang hukum pidana. Peran dari dokter kehakiman dalam penyelesaian perkara pidana di pengadilan adalah membantu hakim dalam menemukan dan membuktikan unsur-unsur yang didakwakan dalam pasal yang diajukan oleh penuntut. Serta memberikan gambaran bagi hakim mengenai laporan dalam visum et repertum.

KUHAP mengingatkan bahwa semua korban karena tindak pidana yang hidup maupun yang mati diperiksa oleh ahli kedokteran kehakiman, baru kalau tidak ada, diperiksa oleh dokter atau ahli lainnya. Hal ini menyebabkan simpang siurnya 
pengertian surat keterangan ahli. Keadaan sebenarnya di rumah sakit di tempat adanya fakultas kedokteran adalah sebagai berikut: ${ }^{4}$

a. Korban luka diperiksa oleh dokter ahli bedah

b. Korban kejahatan kesusilaan diperiksa oleh dokter ahli kebidanan danpenyakit kandungan (obgyn).

c. Korban keracunan diperiksa oleh dokter ahli penyakit dalam.

d. Korban mati diperiksa oleh ahli kedokteran kehakiman.

Semua dokter ahli atau dokter umum dapat melayani permohonan visum etrepertum. Yang paling tepat adalah permohonan ditujukan kepada ahli kedokteran kehakiman berstatus pegawai negeri sipil, dokter ahli lain berstatus pegawai negeri sipil atau dokter umum berstatus pegawai negeri sipil.

\section{Pentingnya Kehadiran Tenaga Kerja Profesional}

Suatu kewajiban bagi penyidik untuk melakukan suatu pengungkapan kasus, karena memang hal tersebutlah pekerjaannya. Akan tetapi kerap terjadi suatu kasus yang sangat sulit untuk dipecahkan dengan berbagai macam kendala yang ada. Akan tetapi secara utilitas penyidik akan merasakan kepuasan yang lebih dari pada sekedar prestasi apabila dapat mengungkap suatu kasus tindak pidana yang sangat sulit diungkap, contohnya seperti kasus pembunuhan yang di mana korban sudah dimakamkan selama 3 (tiga) bulan, dan saksi-saksi sudah banyak yang berpindah ke luar kota bahkan ada yang sudah kehilangan kontak dengan para penyelidik ataupun keluarganya.

Dari hambatan-hambatan yang ada tersebut tidak mematahkan semangat dari para penyidik untuk tetap melanjutkan penyelidikan terhadap kasus tersebut. Para penyidik menelusuri ulang rangkaian kejadian mulai dari TKP, orang tua korban, saksi-saksi yang masih ada. Akan tetapi setelah beberapa hari tetap tidak diketemukan suatu petunjuk baru. Untuk itu para penyidik memutuskan untuk memanggil kehadiran tenaga ahli, dalam hal ini adalah dokter forensik untuk melakukan ekshumasi. Ekshumasi adalah suatu tindakan medis yang dilkukan atas dasar Undang-undang dalam rangka pembuktian suatu tindakan pidana dengan menggali kembali jenazah yang sudah dikuburkan dan berdasarkan izin dari keluarga korban. Akhirnya dengan dilakukannya proses tersebut oleh tenaga ahli, kembali penyidik mendapatkan petunjuk baru yang lebih jelas. Jadi peran

$$
9 .
$$

${ }^{4}$ Njowito Hamdani, 1992, Ilmu Kedokteran Kehakiman, Gramedia Pustaka Utama, Jakarta, hlm 
tenaga ahli dalam proses penyelidikan kasus ini berandil besar dalam penyelesain kasuskasus pidana yang membutuhkan tenaga ahli tersebut.

Tenaga ahli dalam penanganan kasus memang sangat besar pengaruhnya, tidak lupa akan peranannya pada saat melakukan olah TKP sewaktu Bom Bali. Kasus terorisme dapat diungkap dengan keahliannya. Di sini kita semua menyadari bahwa kehadiran mereka sangat membantu dan bahkan sangat diperlukan dalam penanganan kasus tindak pidana. Definisi keterangan ahli menurut Pasal 1 angka 28 KUHAP adalah keterangan yang diberikan oleh seorang yang memiliki keahlian khusus tentang hal yang diperlukan untuk membuat terang suatu perkara pidana guna kepentingan pemeriksaan.

Dalam perkara pidana, keterangan ahli diatur dalam Pasal 184 ayat (1) KUHAP yang menyatakan bahwa alat bukti yang sah dalam pengadilan salah satunya adalah keterangan ahli. Lebih lanjut Pasal 186 KUHAP yang mengatakan bahwa keterangan ahli ialah apa yang seorang ahli nyatakan disidang pengadilan. Mengenai peran ahli dalam memberikan keterangannya dalam pemeriksaan di persidangan terdapat sejumlah peraturan dalam KUHAP, antara lain :

Pasal 132 ayat (1) KUHAP:

Dalam hal ini diterima pengaduan bahwa sesuatu surat atau tulisan palsu atau dipalsukan atau diduga palsu oleh oleh penyidik, maka untuk kepentingan penyidikan, oleh penyidik dapat dimintakan keterangan mengenai hal itu dar orang ahli.

\section{Pasal 133 ayat (1) KUHAP}

Dalam pasal penyidik untuk kepentingan peradilan menangani seorang korban baik luka, keracunan ataupun mati yang diduga karena peristiwa yang merupakan tindak pidana, ia berwenang mengajukan permintaan keterangan mengajukan permintaan keterangan ahli kepada ahli kedokteran kehakiman atau dokter dan atau ahli lainnya.

Pasal 179 ayat (1) KUHAP

Setiap orang yang diminta pendapatnya sebagai ahli kedokteran kehakiman atau dokter atau ahli lainnya wajib memberikan keterangan ahli demi keadilan.

Dapat kita lihat dari apa yang tertera dalam KUHAP bahwa keterangan ahli merupakan salah satu alat bukti, berarti itu menunjukan bahwa keterlibatan seorang ahli dalam penyidikan sangatlah penting. Dimana pengungkapan tindak pidana bisa didapatkan dari keahliannya. 
KRTHA BHAYANGKARA | Volume 15 Number 1, June 2021

\section{B. Kendala Dalam Peranan Ilmu Forensik Terhadap Tindak Pidana Kekerasan Fisik Dalam Lingkup Rumah Tangga Sesuai Putusan No: 1550/Pid.Sus/2015/PN.Mks}

Dalam suatu proses penyelidikan dan penjatuhan sanksi pidana dalam hal ini kasus kekerasan dalam lingkup rumah tangga, sering kita jumpai berbagai kendala yang dihadapi, baik dalam penyelidikan maupun dalam penjatuhan sanksi dalam persidangan.

\section{Kristian menjelaskan (wawancara tanggal 29 Juli 2016) :}

Hakim dalam membuat putusan harus memperhatikan segala aspek di dalamnya. Dalam kasus ini penting diketahui bagaimana hasil visum et repertum untuk mengetahui bagaimana seorang hakim dalam menjatuhkan putusan tidak keliru, seringkali hakim juga menemui kendala dalam hal itu, pada kasus ini kendala yang ditemukan oleh hakim adalah kadang keterangan dari saksi yang berbelit belit, seakan tidak ada kesusian alur cerita dengan saksi yang lain dan kendala yang lain adalah saksi juga kadang tidak hadir dalam persidangan.

Bahwa kita ketahui sangat pentingnya keterangan dari saksi dan terdakwa, jika keyakinan hakim didasarkan atas alat-alat bukti yang tidak dikenal dalam undang- undang atau atas bukti yang tidak mencukupi, misalnya dengan keterangan hanyadari seorang saksi saja, ataupun karena keyakinan tentang itu sendiri tidak ada. Oleh karena hakim adalah seorang manusia biasa yang tentunya dapat salah raba dalam menentukan keyakinannya perihal penjatuhan saksi. Menurut Pasal 189 ayat (1) KUHAP, keterangan terdakwa adalah apa yang terdakwa nyatakan di dalam persidangan tentang perbuatan yang dilakukan atau yang ia ketahui sendiri atau ia alami sendiri.

Kendala yang berbeda juga ditemui oleh dokter yang melakukan visum pada saksi korban, karena dalam penyeledikan suatu laporan tertulis dari dokter yang telah disumpah tentang apa yang dilihat dan ditemukan pada barang bukti yang diperiksanya serta memuat pula kesimpulan dari pemeriksaan tersebut guna kepentingan peradilan, adapun menurut pendapat dari Mauluddin menjelaskan (wawancara tanggal 9 Agustus 2016) :

Kendala yang paling utama dihadapi adalah surat itu terkadang tidak bersamaan dengan barang bukti yang dimintakan, jadi sering kali surat permintaan dari penyidik itu sering terlambat. Permasalahan atau kendala yang terjadi hanya ada pada administrasi surat yang dilakukan penyidik dalam kaitannya ini polisi ke dokter yang melakukan visum terhadap saksi korban. Keterlambatan terjadi karena adanya proses visum et repertum yang terlalu lama, dalam suatu penyelidikan surat yang dikeluarkan oleh dokter dari laporan et repertum harus sesuai dengan KUHAP. Visum et repertum berbeda dengan catatan medik dan surat keterangan medik lainnya karena visum etrepertum dibuat atas 
kehendak Undang-undang yang berlaku, maka dokter tidak dapat dituntut karena membuka rahasia pekerjaan sebagaimana diatur dalam Pasal 322 KUHP, meskipun dokter membuatnya tanpa seizin pasien dan selama visum et repertum dibuat untuk dipergunakan dalam proses peradilan, maka dalam tahap administrasi laporan dari hasil visum et repertum memakan waktu sehingga menemui kendala sesuai dengan hasil wawancara dengan narasumber.

Secara umum penegakan hukum dapat diartikan sebagai tindakan menerapkan perangkat sarana hukum tertentu untuk memaksakan sanksi hukum guna menjamin pentaatan terhadap ketentuan yang ditetapkan. Berhasilnya suatu proses penegakan hukum sangat bergantung pada penerapan hukum pidana, dimana peran penegak hukum salah satunya adalah bagaimana mengaktualisasikannya dengan baik di dunia nyata. Surat dakwaan merupakan dasar pemeriksaan dalam sidang pengadilan, sedangkan surat tuntutan adalah surat yang berisi tuntutan penuntut umum terhadap suatu tindak pidana. Pada hakikatnya, seorang Jaksa Penuntut Umum harus membuat surat dakwaan dan surat tuntutan yang membuat terdakwa dari suatu tindak pidana tidak dapat lolos dari jerat hukum. Hakim dalam memeriksa suatu perkara tidak boleh menyimpang dari apa yang dirumuskan di dalam surat dakwaan. Seorang terdakwa hanya dapat dijatuhkan hukuman karena telah terbukti dalam persidangan bahwa ia telah melakukan tindak pidana seperti apa yang disebutkan jaksa dalam surat dakwaannya.

\section{Analisis Putusan Terhadap Tindak Pidana Kekerasan Fisik Dalam Lingkup Rumah Tangga Sesuai Putusan No : 1550/Pid.Sus/2015/PN.Mks}

\section{Kasus Posisi}

Bahwa benar pada Jum'at tanggal 20 Juni 2014 sekitar pukul 19.30 wita, bertempat di Jalan Urip Sumoharjo depan bengkel Yamaha Sinar Alam Pratama kota Makassar, ia terdakwa Patricya Nurtanio melakukan tindak pidana yang dilakukan dengan cara berikut:

Bahwa berawal ketika saksi korban Ronny hendak menjemput terdakwa dan telah janjian via telepon untuk bertemu di depan Showroom mobil Hyundai, akan tetapi keadaan lalu lintas saat itu tidak memungkinkan sehingga saksi korban terus menjalankan kendaraannya mencari tempat parkir dan saat hendak menelfon terdakwa, terdakwa sudah lebih dahulu menelfon saksi korban dan menyuruh saksi korban untuk pulang saja, namun saksi korban tetap berupaya untuk menjemputnya sehingga saksi korban meminta untuk menemuinya di depan Bengkel Yamaha Sinar Alam Pratama, setelah berada di 
depan bengkel tersebut terdakwa juga tiba dan langusung membuka pintu mobil saksi korban sambil berkata "Kau pulang saja anjing" lalu terdakwa melempari saksi korban dengan menggunakan Handphone miliknya yang mengenai bagian pelipis kiri saksi korban.

\section{Surat Dakwaan}

Berdasarkan posisi kasus di atas, maka jaksa penuntut umum membuat surat dakwaan dalam tahap penuntutan sesuai dengan Berita Acara Pemeriksaan (BAP) dari penyidik. Adapun surat dakwaan adalah sebagai berikut :

Pertama:

Bahwa ia terdakwa Patriciya Nurtanto, pada hari Jumat tanggal 20 Juni 2014 sekitar pukul 19.30 wita, bertempat di Jalan Urip Sumoharjo depan bengkel Yamaha Sinar Alam Pratama kota Makassar atau setidak-tidaknya disuatu tempat lain yang masih termasuk dalam wilayah Hukum Pengadilan Negeri Makassar, telah melakukan kekerasan fisik dalam lingkup rumah tangga terhadap saksi korban Ronny yaitu suami sah dari terdakwa sebagaimana kutipan Akta Perkawinan Nomor 7371-KW-02012012-0011 yang dibuat pada Kantor Dinas Kependudukan dan Catatan Sipil KotaMakassar, yang mana telah menyebabkan saksi korban mengalami luka lecet dibagian pelipis kiri saksi korban, dengan cara-cara sebagaimana telah dicantumkan dalam posisi kasus di atas.

Hal tersebut berdasarkan hasil Visum Et Repertum Nomor: VER/18/VI/2014/Rumkit tanggal 21 Juni 2014 atas nama Ronny, jenis kelamin Laki-laki umur 32 tahun, yang dibuat dan ditanda tangani oleh dr. Mauluddin,M.Sp.F, dokter pada Rumah sakit Bhayangkara Makassar dengan kesimpulan hasil pemeriksaan hasil sebagai berikut:

1. Telah diperiksa seorang korban hidup, berjenis kelamin laki-laki dan berusia dewasa.

2. Ditemukan luka lecbet disertai memar pada alis kiri akibat trauma tumpul. Perbuatan Terdakwa sebagaimana diatur dan diancam pidana menurut Pasal 44 ayat (1) Undang-Undang Nomor 23 Tahun 2004 Tentang Penghapusan Kekerasan dalam Rumah Tangga.

Kedua :

Bahwa ia terdakwa Patricya Nurtanto alias PAT pada waktu dan tempat sebagaimana dalam dakwaan pertama di atas, telah melakukan penganiayaan terhadap saksi korban Ronny. 
KRTHA BHAYANGKARA | Volume 15 Number 1, June 2021

Perbuatan Patricya Nurtanto alias PAT tersebut sebagaimana diatur dan diancam pidana menurut Pasal 44 ayat (4) Undang-Undang Nomor 23 Tahun 2004 Tentang Penghapusan Kekerasan dalam Rumah Tangga.

\section{Tuntutan Penuntut Umum}

Berdasarkan berkas perkara dan surat-surat, keterangan saksi dan terdakwa, serta barang bukti yang diajukan di persidangan, maka Jaksa Penuntut Umum menuntut agar Majelis Hakim memutuskan sebagai berikut :

1. Menyatakan Terdakwa Patricya Nurtanio alias PAT terbukti secara sah dan meyakinkan bersalah melakukan tindak pidana kekerasan dalam rumah tangga, sebagaimana diatur dan diancam pidana dalam Pasal 44 ayat (4) Undang-Undang Nomor 23 Tahun 2004 tentang Penghapusan Kekerasan dalam Rumah Tangga.

2. Menjatuhkan pidana Terdakwa Patricya Nurtanto alias PAT, dengan pidana penjara selama 4 (empat) bulan, dengan perintah agar Terdakwa tetap ditahan.

3. Menetapkan agar Terdakwa dibebani membayar biaya perkara sebesar Rp. 2000,- (dua ribu rupiah) apabila dipersalahkan dan dijatuhi pidana.

4. Amar Putusan

Adapun yang menjadi amar putusan dalam perkara ini adalah sebagai berikut :

\section{MENGADILI}

1. Menyatakan Terdakwa Patricya Nurtanto alias PAT telah terbukti secara sah dan meyakinkan bersalah melakukan tindak pidana kekerasan fisik dalam lingkup rumah tangga sebagaimana dalam dakwaan.

2. Menjatuhkan pidana kepada terdakwa dengan pidana penjara selama 3 (tiga) bulan.

3. Menyatakan bahwa pidana tersebut tidak perlu dijalani kecuali dikemudian hari ada perintah lain dalam putusan hakim bahwa terpidana sebelum masa percobaan selama 6 (enam) bulan.

4. Membebani biaya perkara kepada terdakwa sebesar Rp.2000,- (dua ribu rupiah).

Dalam posisi kasus, surat dakwaan, tuntutan penuntut umum, danamar putusan di atas terdakwa telah secara sah dan terbukti telah melakukan perbuatan kekerasan dalam rumah tangga yakni berupa kekerasan fisik, sebagaimana diatur dalam dalam Pasal 44 ayat (4) Undang- undang Nomor 23 Tahun 2004 tentang Penghapusan Kekerasan Dalam Rumah Tangga. Hal ini sesuai dengan hasil visum et repertum yang ditangani 
oleh Mauluddin, dokter forensik yang melakukan visum. Bahwa lewat pemeriksaan visum, peranan ilmu forensik dapat berjalan dengan memecahakan kasus-kasus pidana. Hal ini sejalan dengan kutipan hasilwawancara penulis dengan Kristian, hakim dalam perkara ini (wawancara tanggal 29 Juli 2016) yang menyatakan bahwa :

Dalam pengambilan putusan dalam perkara ini peranan ilmu forensik sangat penting, sebab dengan adanya hasil visum menjadi salah satu tolak ukur hakim dalam menjatuhkan pidana pada terdakwa, hal ini juga tertuang dalam KUHAP Pasal 187 butir c yang menyatakan kewajiban dokter untuk membantu peradilan dalam bentuk keterangan ahli, pendapat orang ahli, dan surat keterangan ahli, berdasarkan keahliannya mengenai suatu hal atau suatu keadaan yang diminta secara resmi padanya.

Secara sosiologis, maka penjatuhan hukuman harusnya tidak saja berdasarkan kepastian hukum, tetapi juga berlandaskan asas keadilan dan kemanfaatan yaitu memperhtikan rasa keadilan masyarakat, memulihkan keadilan sosial masyarakat, mencegah orang lain untuk tidak melakukan tindak pidana dan sebagainya. Oleh karena hakim mempertimbangkan keterangan forensik sebagai salah satu alat bukti dalam penjatuhan sangsi pidana. Hal ini kemudian didukung oleh hasil wawancara dengan Kristian (wawancara pada tanggal 29 Juli 2016) yang menyatakan bahwa:

Keterikatan hakim terhadap visum et repertum sebagai alat bukti surat yang sah dapat dilihat pada saat hakim menerima hasil kesimpulan visum et repertum, dan mengambil alih kesimpulan tersebut dan didukung paling sedikit satu alat bukti lain ditambah dengan keyakinan hakim bahwa terjadi tindak pidana penganiayaan dan terdakwalah yang bersalah melakukannya, maka berdasarkan visum et repertum di persidangan, barulah hakim menjatuhkan sangsi pidana.

Dalam hal ini penulis juga berkesempatan melakukan wawancara dengan Mauluddin. Dokter yang melakukan visum dalam perkara ini (wawancara dilakukan pada tanggal 9 Agustus 2016), yang menyatakan sebagai berikut :

Sesuai dengan aturan perundang undangan yang ada di negara kita yaitu dalam KUHAP, salah satu alat bukti yang nanti bisa menjadi atau membuktikan perkara pidana nanti adalah keterangan ahli dan hasil visum sebagai alat bukti kategori surat. Dokter forensik setelah menerima pekerjaan untuk membuktikan perkara pidana tadi maka dia menuangkannya dalam bentuk visum et repertum. Jadi peranan forensikyang pailng penting adalah melakukan pemeriksaan pada korban dan menuangkan hasil pemeriksaan dalam bentuk visum et repertum untuk pembuktian dalam persidangan. 
Berhasilnya suatu proses penegakan hukum sangat bergantung pada penerapan hukum, di mana peran penegakan hukum salah satunya adalah bagaimana mengaktualisasikannya dengan dengan baik di dunia nyata.

\section{Analisis}

Kekerasan fisik yang dilakukan dalam lingkup rumah tangga yang dilakukan olehterdakwa Patricya Nurtanto alias PAT terhadap suaminya, yakni saksi korban Ronny. Dalam kasus ini, surat dakwaan Jaksa Penuntut Umum secara teknis telah memenuhi syarat formil surat dakwaan sebagaimana dimaksud Pasal 143 Ayat (2) KUHAP, yaitu harus memuat tanggal dan ditandatangani oleh penuntut umum serta identitas lengkap terdakwa. Selain itu juga, surat dakwaan harus memuat uraian secara cermat, jelas dan lengkap mengenai tindak pidana yang didakwakan dengan menyebut waktu dan tempat tindak pidana itu dilakukan.

Hakim dalam pemeriksaan perkara pidana berusaha mencari dan membuktikan kebenaran materiil berdasarkan fakta-fakta yang terungkap dalam persidangan serta berpegang teguh pada apa yang dirumuskan dalam surat dakwaan Jaksa Penuntut Umum. Berdasarkan posisi kasus yang telah diuraikan di atas maka dapat disimpulkan telah sesuai dengan ketentuan baik hukum pidana formil maupun pidana materiil dan syarat dapat dipidananya seorang terdakwa. Hal ini didasarkan pada pemeriksaan dalam persidangan, di mana alat bukti yang diajukan oleh Jaksa Penuntut Umum saling bersesuaian. Oleh karena itu, Majelis Hakim Pengadilan Negeri Makassar menyatakan bahwa unsur-unsur perbuatan terdakwa terdapat dalam Pasal 44 Ayat (4) Undang-undang Nomor 23 Tahun 2004 Tentang Penghapusan Kekerasan dalam Lingkup Rumah Tangga.

Penjatuhan sanksi pidana dalam dakwaan mengakomodir kronologis kejadian dengan menerapkan Pasal 44 Ayat (4) Undang-undang Nomor 23 Tahun 2004 tentang Penghapusan Kekerasan Dalam Rumah Tangga, dalam perkara Nomor 1550/Pid.Sus/2015/Pn.Mks ini yaitu terdakwa Patriciya Nurtanto menunjukkan perbuatan kekerasan fisik yang dilakukanistri terhadap suami, melempari saksi korban Ronny dengan menggunakan handphone yang mengenai pelipis kiri korban. Dalam kasus ini menurut penulis sudah tepat diterapkan Pasal 44 Ayat (4), karena sesuai hasil visum et repertum nomor : VER/18/VI/2014/Rumkit pada tanggal 21 Juni 2014, korban hanya mengalami luka lecet disertai memar dan tidak menimbulkan penyakit atau halangan untuk menjalankan pekerjaan. Maka dari itu dengan adanya peran ilmu forensik, kasus ini dapat terpecahkan. 
Peran dari anggota kedokteran kepolisian yang disingkat Dokpol tidak lepas dari disiplin ilmu mereka yang berperan besar dalam mengungkap kasus ini, hal ini sesuai dengan Peraturan Kepala Kepolisian Negara Republik Indonesia Nomor 12 Tahun 2011 Tentang Kedokteran Kepolisian, yang di mana bertujuan sebagai pedoman pelaksanaan tugas bagi para pengemban Dokpol, terselenggaranya Dokpol secara efektif, efisien dan profesional dan terwujudnya pelayanan Dokpol yang prima untuk kepentingan tugas Kepolisian. Maka peran tenaga ahli dari itu semua hakim dapat menilai secara objektif penjatuhan sanksi pada terdakwa dengan menerapkan pasal sesuai hasil visum.

Pemidanaan merupakan suatu proses, yang di mana sebelum proses ini berjalan, peran hakim dan tenaga ahli lainnya sangatlah penting. Ia mengkonkretkan sanksi pidana yang terdapat dalam suatu peraturan dengan menjatuhkan pidana bagi terdakwa. Jadi pidana yang dijatuhkan diharapkan dapat menyelesaikan konflik atau pertentangan dan juga dapat mendatangkan kedamaian dalam masyarakat. Pemidanaan ini tidak dimaksud untuk menderitakan dan juga tidak diperkenakan merendahkanmartabat manusia, namun merupakan pemberian makna kepada sistem hukum Indonesia.

\section{KESIMPULAN}

Dalam kasus ini yaitu, kekerasan fisik dalam rumah tangga yang dilakukan istri terhadap suami studi kasus putusan No.1550/Pid.Sus/2015/PN.Mks yang di mana terdakwa bernama Patriciya Nurtanto alias PAT terbukti secara sah dan menyakinkan telah melakukan kekerasan terhadap saksi korban yaitu saksi korban sendiri adalah suaminya. Sebagaimana diatur dalam Pasal 44 ayat (4) Undang-undang No 23 Tahun 2004 Tentang Penghapusan Kekerasan Dalam Rumah Tangga yang didakwakan ke terdakwa telah tepat, mengingat peranan forensik dalam pengaplikasiannya terlihat dari hasil visum et repertum yang menjadi salah satu acuan majelis hakim dalam menjatuhkan sanksi pidana terhadap terdakwa.

Kendala yang ditemui dalam pembuktian tindak pidana KDRT dalam kasus ini adalah keterbatasan saksi dan alat buktinya, sehingga dalam proses laporan administrasi dari visum et repertum terbatas dari apa yang dilihat dan diketemukan saja, dan kendala dalam suatu putusan hakim adanya keterangan saksi yang berbelit belit, adapun kendala lain dimana tidak hadirnya saksi dalam persidangan. 


\section{SARAN}

Diperlukan adanya pengetahuan dan pemahaman lebih khusus hakim dalam berbagai masalah hukum yang timbul dalam kehidupan masyarkat. Apalagi dalam menangani perkara yang menyangkut kekerasan dalam rumah tangga, hakim dituntut untuk cermat dan menggali nilai-nilai yang hidup dalam masyarakat. Hal ini disebabkan karena dalam perkara kekerasan dalam rumah tangga sudah tentu memiliki nilai-nilai yang berbeda dengan masalah yang sering timbul dalam masyarakat. Sebagian masyrakat yang belum mengetahui dan memahami arti dan kegunaan visum et repertum, sehingga mempunyai keterbatasan dalam suatu putusan, oleh karena itu sangat dimungkinkan untuk menerapkan Pasal 222 KUHP kepada mereka yang dianggap menghalangi-halangi atau mengulur- ulur jalanya persidangan guna kepentingan peradilan. Pemerintah khususnya para penegak hukum harus melakukan sosialisasi tentang akibat hukum atau hukuman pidana yang dapat menjerat pelakuKDRT, serta peran serta masyarakat dengan cara melakukan ceramahceramah agama yang akan disampaikan dalam rangka membentengi diri dari perbuatan keji dan munkar dan lebih tertanam rasa cinta akan keluarga untuk membinah rumah tangga.

\section{DAFTAR PUSTAKA}

\section{Buku}

Abdul Mun'im Idries, 1997, Pedoman Ilmu Kedokteran Forensik, Binarupa Asara, Jakarta. Anshoruddin, 2004, Hukum Pembuktian Menurut Hukum Acara Islam dan Hukum Positif, Pustaka Pelajar, Yogyakarta.

Guse Prayudi, 2009, Berbagai Aspek Tindakan Pidana Kekerasan Dalam Rumah Tangga, Cetakan II, Merkid Press, Sukabumi.

Hari Sasangka dan Lily Rosita, 2003, Hukum Pembuktian Dalam Perkara Pidana, Mandar Maju, Bandung.

Hendra Akhdhiat, 2011, Psikologi Hukum, Pustaka Setia, Bandung.

M. Yahya Harahap, 2005, Pembahasan Permasalahan dan Penerapan KUHAP Pemeriksaan Sidang Pengadilan, Banding, Kasasi, dan Peninjauan Kembali, Sinar Grafika, Jakarta.

Maria E. Pandu, 2013, Bunga Rampai Perempuan Keluarga Gender, Yayasan Bina Generasi Makassar, Makassar.

Mohammad Taufik Makarao, 2013, Hukum Perlindungan Anak dan Penghapusan Kekerasan dalam Rumah Tangga, Rineka Cipta, Jakarta.

Moerti Hadiati Soeroso, 2011, Kekerasan Dalam Rumah Tangga Dalam Perspektif Yuridis- Viktimologis, Sinar Grafika, Jakarta. 
Njowito Hamdani, 1992, Ilmu Kedokteran Kehakiman, Gramedia Pustaka Utama, Jakarta.

R. Soesilo, 1985, Kriminologi (pengetahuan sebab-sebab kejahatan), Politeia, Bogor.

Sudikno Mertokusumo, 1993, Bab-bab Tentang Penemuan Hukum, PT.Citra Aditya Bakti, Bandung.

Susetio Pramusinto, 1984, Himpunan Karangan Ilmu Forensik Suatu Sumbangan Bagi Wiyata Bhayangkara, PT. Karya Unipres, Jakarta.

Tolib Setiady, 2009, Pokok-Pokok Ilmu Kedokteran Kehakiman, Alfabeta, Bandung. Teguh Prasetyo, 2010, Hukum Pidana, PT Rajagrafindo Persada, Jakarta.

Wirjono Prodjodikoro, 2009, Asas-asas Hukum Pidana di Indonesia, PT Refika Aditama, Bandung.

Yulia Monita dan Dheny Wahyudhi, Peranan Dokter Forensik Dalam Pembuktian Perkara Pidana, dalam jurnal ilmiah yang dikeluarkan oleh Ikatan Dokter Indonesia.

\section{Skripsi}

Ramadhan Satria Halim, Fakultas Hukum, Universitas Hassanudin, "Peranan Ilmu Forensik dalam Pengungkapan Tindak Pidana Kekerasan Fisik Dalam Lingkup Rimah Tangga yang Dilakukan Istri terhadap Suami”

\section{Undang-Undang}

Undang-Undang Republik Indonesia No. 1 Tahun 1974 Tentang Perkawinan.

Undang-Undang Republik Indonesia No. 8 Tahun 1981 Tentang Kitab Undang- undang Hukum Acara Pidana.

Undang-Undang Republik Indonesia No. 23 Tahun 2004 Tentang Penghapusan Kekerasan Dalam Rumah Tangga.

Undang-Undang Republik Indonesia No.1 Tahun 1946 Tentang Kitab Undang- undang Hukum Pidana.

Peraturan Kepala Kepolisian Negara Republik Indonesia No.12 Tahun 2011 Tentang Kedokteran Kepolisian. 